\title{
Empirical Research on Task-based Teaching Method in Vocational College Nursing English Teaching
}

\author{
Luo Aiming ${ }^{1, \text { a }}$ \\ ${ }^{1}$ Hubei College of Chinese Medicine, Jingzhou 434020,China \\ a LuoAiming2013@yeah.net \\ Keywords: Task-based approach, Vocational college, Nursing English, Application, Empirical \\ Research
}

\begin{abstract}
This article introduces the definition and function of task-based approach by means of empirical research, and shows that task-based language learning can improve the nursing English skill in vocational college hence make the students study English in a positive way. According to the method, the English reading ability and reading skil was advanced to some extent. So we can get the conclusion that through a teaching experiment, it is proved that the application of task-based approach to Nursing English in vocational college is practical and effective.

Since the task-based teaching method was raised in the 1980s, it received wide range of initiation and utilization. In the recent years of China, the teaching method is raising considerable concern in the teaching field. Nevertheless, the education that is combined the task-based teaching method with nursing english is still not be carried out. So it is significant to take a step forward to knowing the quality of task-based teaching method and study the nursing english in higher vocational college's teaching application. It will be beneficial for us to adopt the good teaching mode and to get the teaching efficiency.
\end{abstract}

\section{The definition and function of task-based teaching method}

The task-based language teaching method refers to an approach based on the use of tasks as the core unit of planning and instruction in language teaching, it also known as task-based language learning focus on the use of authentic language and on asking students to do meaningful tasks using the target language. Such tasks can include visiting a doctor, conducting an interview, or calling customer service for help. Assessment is primarily based on task outcome rather than on accuracy of language forms. This makes task-based teaching method especially popular for developing target language fluency and student confidence. It is an teaching method that emphasis on learning by doing that raised in 1980s, also known as a development of communicative approach, and get wide ranged attention of all the language educational world. For the past few years, the introduction of such teaching theory like doing things with the language to Chinese basic English teaching class is a huge move towards of foreign language course teaching reform. It consider that instead of training language skills and learning the language knowledge, to get hold of language mainly is the result of using language in the motivation. In the process of pedagogical practices, teachers should design specific and operable mission that centre on the certain communication and language project, the students learn to communicate through interaction and attempt to link language classroom learning with language activation outside the classroom and carry the point of learning language. The task-based teaching method was formed via the absorption of many different teaching methods as usual, by which I mean it's not reject the other methods.

The constitutive property of task-based teaching method is consists of teacher and student's role, the goal of teaching and teaching environment. It means that the leaners cannot only lay emphasis on language itself, but also the process of language acquisition, it may needs more attention to the interaction and cooperation. According to the relative simulation task, students can accomplish their assignment via the activity like group discussion or role play, and in the process of doing this can help students enhance their learning initiative, and redeploy their positive emotion factors and cultivate the cooperative awareness and cognitive competence as well. On the other hand, task-based motivated student's individual experience of finish the accomplishment positively, thus 
finish the understanding, operating and utilizing of language learning and training. So it is highly proved that the application of task-based approach to Nursing English in vocational college is practical and effective.

\section{The necessity and feasibility of task-based teaching method in vocational college nursing English teaching}

Higher vocational education is booming in recent years, alone with the development of global economy and China's strategy of opening up and the background of aged tendency of population, the shortage of nurse major is getting worse, the demand of inter-disciplinary talent who knows not only nursing knowledge but also the ability of English is ever-increasing. While the ministry of education issues the requirement of English curriculum requirements of Higher Occupation Education, it is said that we should setting the English curriculum with the goal of cultivate the student's language communication ability in the job market. Therefore, many educationalist and English teacher in high vocational school are undergoing continuously attempt and exploration in the English teaching of nursing major, yet the teaching efficiency is not as ideal as that much, the majority of nursing students' English applicative ability is far not enough to get the requirement of hospitals and the practical demand of work.

The teaching characteristics of high vocational school's nursing English is the objective reality, nursing English is a complex curriculum system, it's main teaching content is words and vocabulary, daily conversation, nursing knowledge and nursing difference of Chinese and Western, what we should notice that the emphasis on technological process and language application have strong practicability. Nowadays, most of the students in high vocational schools have weak English basic in their minds, they have no interests in test and English learning. While the hospitals in the large and medium-sized cities have highly demand to those who's in nursing major, they're required to communicate with patients fluently when it is necessary and able to make out the simple English case, while look up the English material at the same time. If a student cannot satisfy the conditioin like this, it is for sure that they may lose some wonderful job opportunities. To deal with the contradiction between cultivation aim and the current situation of students requires teacher to avoid the traditional teaching method that just impart the language knowledge, but to adopt the task-based teaching method that have the feature of practicalness and have the clear objective, hence to make students get close to their real life, and let them be a part of it, to learn to cooperate in the learning of language.

As a brand new teaching idea and teaching mode of activity, the task-based teaching method is known and accepted by more and more English teaching educators. It shows a kind of approach hat use mission as the core plan to organize and put the second language teaching into effect. Nursing English teaching belongs to a branch of English for specific purpose(ESP), it means the special English language teaching should give up the traditional teaching conception and built the new one that teach the English as the tool for communication, hence to cultivate the students' ability to use English in different practical environment. It is no doubt that the task-based language learning provides a train of thought to solve the problem like this.

\section{The application of task-based teaching method in vocational school}

\section{a. The research purpose and methods}

The research purpose is to compare the task-based language learning and traditional teaching method and verify the teaching efficiency according to the application in vocational school's English teaching.

The study selected two classes in the vocational school that I was taught, one class were taught in traditional ways and the other were instructed with task-based teaching method. Before the test started, it was found that there were no obvious differences between last term's final examination score of two classes according to the analyzis. The teaching material was English for International 
Nursing Reference Book that published by ELTRP, the time is 4 class hour per week that taught by myself.

\section{b. Experimentation}

In the process of research, we follow the rules of scientificity, practicability and focus on the cultivation of student language ability at work, and make effort to create the scene of simulation authenticity, just in order to get the students' awareness of how to utilize English in the future work. The basic framework of the research is the task-based teaching method of Willis, while incorporate the learning situation of high vocational school's nursing major, to carry through the task-based teaching practice by the five basic procedures. The first step is presenting the task, there is an old saying goes, a good begging makes a good ending, the adoption of presentation would directly guide the students into the relative situation, and activate their interest for it. The second step is preparation work. The point of this phase is mean to let the students get the information that related to their mission, and then to provide the requiring language knowledge or skills to accomplish the assignment. Next step is execution of mission which also known as the key point of the research. In this phase, students finish the mission by group basis according to the demand, teacher should report the method, object and time in detail, so that it can be convenient for students to prepare with purpose in the preparing step. In the reporting part, the leader of each group should report their research while others listening and taking notes and comparing the results. After all these, teacher needs to make a short evaluative feedback to make sure their effort. The forth step is the evaluate and analyse of mission that include two links which are the analysis of language form and the evaluation of assignment. The aim of doing this is to help students know the correct usage of relative grammar, phrase match and words, and reinforce the learning spot that related to their mission. The last step is to assign homework that have something to do with the mission, according to the paper work or the verbal work, students can understand their learning in a better way, on the other hand, this step have the function of consolidate the knowledge.

\section{c. Data analysis}

Both classes had the Nursing English Proficiency Test after the research of one semester, the testing material was the Medical English Test System for Nurses (Level2), the test was hosted by Ministry of Education Test Center, Chinese Nursing Association and China Association for International Exchange of Personnel, by which I mean it has strong pertinency for nursing. Meanwhile, I compare the testing score of Practical English Test for Colleges (A Level). It turns out that from both testing result we can find the obvious difference between them, the research shows that the class which received the task-based teaching method shows the higher efficiency. We can tell that the application of task-based approach to Nursing English in vocational college is practical and effective. It is obvious that compare with the traditional teaching method, task-based teaching put more attention on students' confident awareness and the improvement of their comprehensive quality's like collaboration ability, so it is highly suggested that the teaching method is feasible and practicable in the English education of vocational school.

\section{Summary}

According to the relative reference and empirical research, it is obvious that the task-based teaching method adopted in high vocational school's nursing English teaching is able to improve the English skills of students, and have the advantage to enhance their English comprehensive ability. It is advantageous to the student because it is more student-centered, allows for more meaningful communication, and often provides for practical extra-linguistic skill building. Although the teacher may present language in the pretask, the students are ultimately free to use what grammar constructs and vocabulary they want. This allows them to use all the language they know and are learing, rather than just the "target language" of the lesson. Furthermore, as the tasks are likely to be familiar to the students, students are more likely to be engaged, which may further motivate them in their language learning. While there have been criticisms that task-based learning is not appropriate as the foundation of a class for beginning students. The major disadvange for 
beginning students is that the focus of task-based language learning is on output, when beginning language learners often go through a silent period requiring massive amounts of comprehensible input. Others claim that students are only exposed to certain forms of language, and are being neglected of others, such as discussion or debate, teachers may want to kee these in mind when designing a task-based learning lesson plan. We all know that every coin has two sides, so if we see the point from this angle, although the utilize of the method is still in the exploratory stage, but to list the task-based teaching method in the nursing English teaching is totally worth to try, it will be favored and admired by more teachers and students, the advantage of the teaching method stands to a certain reason.

In a word, we should recommend the task-based teaching method into the education of nursing major on the basic of analyse the teaching content of vocational nursing English. Let the students learning English in the process of accomplish their assignment, it will be an effective cultivation which aimed at training students’ English command.

\section{Reference}

[1] Ellis. R. Task-based Language Learning and Teaching. Oxford:Oxford University Press, 2003.

[2] Willis. J. A Framework for Task-based Learning. Lon-don:Longman Addison Wesley, 1996.

[3] Wei Yonghong, Task-based Foreign Language Teaching and Research, Shanghai: ECNU Press,2004.

[4] Cheng Kela, Task-based Foreign Language Research, Shanghai: ECNU Press,2004.

[5] Cheng Xiaotang, Task-based Teaching Method, Higher Education Press, 2004. 